\title{
Scientific Research and the Glass Industry in the United States.
}

\author{
By Dr. M. W. Travers, F.R.S.
}

THE great American glass works engineer, Mr. Owens, referring to the fact that he had been refused admission to an English glass works, once observed to a friend of mine, "If a man refuses to admit me to his plant I generally reckon that he is ashamed of it." I had often wondered whether Mr. Owens's countrymen really practised the policy which he preached, and last autumn the opportunity offered of putting it to the test. During a seven weeks' tour through the States I paid almost daily visits to glass plants, with no other introduction than the information conveyed by my private visiting card, and only once was my visit restricted to the office. Generally I was shown the whole plant, and all my questions were frankly answered; sometimes I was even permitted to make a second round of the works on my own account. In the research laboratories of both private companies and great industrial corporations I was made doubly welcome. I can only express a sense of obligation, which I can never repay.

It was very frequently that I heard statements made to the effect that the application of science to industry in America was only in its infancy. It is a fact that American industry is absorbing the whole output of the universities, and also drawing men from this country. America has found the application of science to industry to be a proposition which appears to be a sound one, and, in conformity with American industrial policy, means to give science a fair trial. If men of science prove their value from the commercial point of view, they will rank equally with men of business capacity, who are able to dictate the terms of their service to industry.

It must be remembered that the American glass industry is relatively small, and even in Pittsburgh, where the glass factories are most numerous, it is entirely overshadowed by the steel industry. However, so far as scientific research goes, the industry is in a remarkably favourable position. The Geophysical Laboratory at Washington, D.C., which I visited, is primarily an institution for the investigation of scientific problems connected with glasses, of which the earth itself so largely consists, and the Bureau of Standards has devoted a considerable amount of attention to the subject. In April, I9I7, soon after America joined in the war, American industry had to face a demand for an immense amount of optical glass. The work done by the staff of the Geophysical Laboratory is told in a few words in the director's report for I918: "Suffice it to say that with a staff of twenty scientifically trained men, all trained in the handling of silicate solutions at temperatures required for the making of glass, and familiar with the control of the most important factors in the problem, it proved practicable to make rapid progress." After two months the output had doubled, and rejections by Government inspectors had become NO. 2627 , VOL. IO5] very rare. A few months later "the output had reached a magnitude such that an adequate supply of suitable glass was assured for national needs, and . . . many refinements were being effected to bring the quality of the glass to a higher level."

To achieve these results, the staff of the Geophysical Laboratory did not remain in Washing. ton and issue advice to manufacturers, but actually took over the scientific control of the plants, some of which were built after America's entry into the war, and in such positions I still found some of them when I was in America. The Bureau of Standards also established a small manufacturing plant in Pittsburgh, and here some very important work on glass pots for optical glass manufacture was carried out by Dr. Bleiniger. Accounts of much of this work have been published in the American Journal of Science and the Journal of the American Ceramic Society, and the work is described as being carried out "at the Geophysical Laboratory and at the plants of the Bausch and Lomb Optical Co., Spencer Lens Co., and Pittsburgh Plate Glass Co., under the authority of the War Industries Board." Anyone who is interested may learn exactly what was accomplished and what the position is at the moment, and may visit such of the plants as are in operation. Can anyone say what really has been accomplished in connection with optical glass in this country, what remains to be done in order to establish the industry, and what organisation exists for doing it?

The Bureau of Standards is, of course, an official institution; the Geophysical Laboratory is maintained by the Carnegie Institution, and is not under the control of Government. I do not know how far the experimental work in connection with optical glass was subsidised by the Federal Government, but during the war very substantial funds for research work were at the disposal of the National Research Council, which was organised, at the request of the President, by the National Academy of Sciences, and money from this source was available for such purposes. It must be noted that wherever an appointment had to be made in any matter of a scientific character, even in the case of officials, it was made on the recommendation of the men of science. In this we find an essential difference between American and British practice.

The development of scientific glassware, other than optical glass, was left to individual effort, and was solved with equal success by several firms. The Corning Glass Works, at Corning, N.Y., succeeded, however, in producing a very remarkable glass, which is called "Pyrex" glass, from which are manufactured both chemical hollow-ware and the so-called oven-ware. This glass has so low a coefficient of expansion and so high a tenacity that one can take extraordinary liberties with it, and it is much more highly resistant to changes of temperature than any glass previously produced. The 
production of this glass is a very remarkable achievement.

"Pyrex" glass and the Empire bulb-blowing machine were only two of the many interesting developments which I was shown at Corning. When I was there, Dr. A. L. Day, who has long been connected with the works, was acting as vice-president of the company; and Dr. E. C. Sullivan and Dr. W. C. Taylor, assisted by a considerable scientific staff, were in charge of the technical side of the work. Dr. Taylor told me that they had been carrying out a systematic survey of possible combinations in glasses, and that as each glass was made experimentally its properties were investigated and recorded. In the Steuben Works, which are under the same management, and only a few hundred yards distant, Dr. J. C. Hochstetter was collaborating with Mr. F. C. Carder in the investigation of problems relating to coloured glasses.

Scientific glassware was also being manufactured at the H. C. Fry Glass Works, where I spent a day with Dr. Scholes and his staff, and at the Macbeth Evans Glass Co.'s plant, also near Pittsburgh, Pa., over which I was shown by Dr. Macbeth and Prof. Hower, who is consultant to the firm. I found quite a numerous scientific staff working in excellent laboratories.

In the bottle-making branch of the industry the engineer predominates. I believe that the first bottle machine was English, and one would like to know why it is that the development of bottle machinery has been practically wholly American. The Owens machine, the Hartford-Fairmont flow feed, the Westlake machine, and the Empire machine are purely American, and they are American because Americans. understand the value of science organised in the service of industry, and are willing to give good brains a fair chance and to back them with good money. Developments in this direction are entirely a matter of private enterprise, in which consumers as well as manufacturers are often financially interested.

To no branch of the glass industry has science been of greater service than to that of the electric lamp industry. I was able to spend two days in the research laboratories attached to the great plant of the General Electric Co. at Schenectady, in company with Drs. Whitney, Langmuir, Coolidge, and Hull, whose names are as well known in Europe as in America. The staff of the laboratory is said to number more than 150 members, and the work carried on is in some cases purely scientific, and in others highly technical, processes being actually worked in the laboratory until the demand for the goods or material produced justifies the erection of separate factories. While I was at Cleveland, Ohio, Dr. W. M. Clark, the chief chemist of the National Lamp Association, was good enough to show me over the whole plant of his firm. Here a physical laboratory dedicated to investigations connected with illumination, but only indirectly with artificial lighting, has been established in recognition of the services of science to the industry.

In several of the universities research is being carried out in connection with glass, and I had the good fortune to meet both Prof. Washburn, of Illinois University, and Prof. Silverman, of Pittsburgh University, and to discuss with them their work on the chemistry and physics of glass.

A short article permits me to deal only with isolated incidents in my tour, but the impression which I brought away with me and wish to convey to others is that there are a great many men of high scientific ability engaged in the American glass industry, which has learned, as the German glass industry learned, to our undoing, that industrial progress implies the co-operation of science and industry. American industry is not securing the co-operation of science for sentimental reasons, but with a view to competition with us in the markets of the world. To this movement science, through the National Research Council, organised by the National Academy of Sciences, in co-operation with the national scientific and technical societies of the United States, is giving its heartiest support.

\title{
The Circulating Blood in Relation to Wound-Shock. ${ }^{1}$
}

\author{
By Prof. W. M. Bayliss, F.R.S.
}

THE system of vessels in which the blood is contained must be conceived of as a closed system. But the walls are distensible and elastic; they can therefore stretch and collapse to accommodate varying amounts of liquid. This is possible, however, only to a limited extent. Although the veins have thinner walls than the arteries, and appear to be less supported by surrounding structures than are the capillaries, it is remarkable that they oppose a greater resistance to a bursting pressure than do the arteries. Veins, moreover, have a muscular coat which is in a

\footnotetext{
1 Discourse on "The Volume of the Blood ard its Significance," delivered at the Royal Institution on Friday, February $\mathrm{I}_{3}$.

NO. 2627 , VOL. IO5]
}

more or less contracted state during life. Hence the introduction of more fluid into the system must encounter a certain resistance and raise the internal pressure, unless the muscular coat actively relaxes to accommodate the fluid introduced.

This closed system contains, under normal conditions, about four litres of blood in man. It consists, as is generally known, of the heart, of branching tubes (arteries), leading from the heart to the tissues, where they break up into a network of much finer tubes, the capillaries, which unite again to form the veins, and so lead the blood back to the heart. Consider the distribution of the blood at the time when the heart is at rest. 